\title{
A Rare Case of Neonatal Hyperinsulinemic Hypoglycemia
}

\author{
Shanty G Shah, Avinash S, Shenoy KV, Sudeep K* \\ Department of Endocrinology and Department of Peadiatrics \\ Father Muller Medical College Hospital, Mangalore 575002, India
}

BACKGROUND
INVESTIGATIONS
Hyperinsulinemic Hypoglycemia refers to low plasma glucose levels in the presence of inappropriate insulin secretion by pancreatic $\beta$ cells. Congenital Hyperinsulinism is one of the most common cause of nonketotic prolonged severe hypoglycemia in neonates. This is a rare condition affecting 1 in 50,000 live births. ${ }^{1}$

We report a case of severe Hyperinsulinemic Hypoglycemia in a neonate.

\section{CASE PRESENTATION}

A 1 day old full term male infant, delivered by Caesarean section presented with severe hypoglycemia few hours after birth. His birth weight was $3.6 \mathrm{~kg}$, APGAR score was 8 and 9 at 1 and 5 minutes. He was born to nonconsanguineous parents. Mother did not have a history of gestational diabetes mellitus or intake of any medications during pregnancy.

General physical examination was unremarkable except for tachypneoa for which he was closely monitored.

Glycemic monitoring revealed persistent hypoglycemia with a recording of plasma glucose $43 \mathrm{mg} / \mathrm{dl}(2.3 \mathrm{mmol} / \mathrm{L}), 14 \mathrm{mg} / \mathrm{dl}(0.7 \mathrm{mmol} / \mathrm{L})$. Simultaneous Cortisol and GH levels were $690 \mathrm{nmol} / \mathrm{l}(171-536),>10 \mathrm{ng} / \mathrm{ml}$ respectively and Urine ketones negative. Serum TSH was : $8.53 \mathrm{mIU} / \mathrm{ml}$ (1-39), Free T4: 2.32 $\mathrm{ng} / \mathrm{dl}$ (0.93-1.7). Serum insulin was inappropriately elevated $16 \mathrm{mIU} / \mathrm{L}$ with a corresponding plasma glucose 39mg/dl and Insulin-Glucose ratio $0.41(<0.25)$. Post Glucagon challenge the plasma glucose rose by $>30 \mathrm{mg} / \mathrm{dl}(1.6 \mathrm{mmol} / \mathrm{L})$.

18 F- DOPA PET/CT confirmed diffuse enhancement in pancreas with higher intensity at head and neck region.

Genetic investigation revealed two heterozygous mutations (Asp854Asn and Arg1394cys) in the ABCC8 gene.

\section{DISCUSSION}

Hyperinsulinemic hypoglycaemia $(\mathrm{HH})$ in neonates, formerly described as Congenital Hyperinsulinism is characterised by persistently elevated insulin secretion resulting in severe persistent hypoglycaemia. ${ }^{1,2}$ Already known etiology include inactivating mutations of the K-ATP channel genes (ABCC8 and KCNJ11), HNF4A, HNF1A, HADH, and UCP2 or activating mutations of GLUD1, GCK, and SLC16A1.4

Mutations of ABCC8 and KCNJ11 are likely the main causes of K-ATP-HH as seen in our patient. The most widely accepted treatment is initial Glucose infusion as first line to normalise glycaemic level, Octreotide as second line in order to reduce the high Glucose infusion rate (GIR) and Diazoxide (K-ATP channel agonist) as a definitive medical line of management when diagnosis is confirmed. ${ }^{3,4}$

We successfully discontinued Diazoxide therapy in our patient at age 3 although not much information regarding this is available in literature. A recent study (2018) reports discontinuation of Diazoxide at a median age of 6.8 years in 5 children with Diazoxide- responsive probands HNF1A- and HNF4A ${ }^{5}$

\begin{tabular}{|c|c|c|}
\hline INVESTIGATIONS & WEEK 1 & WEEK 2 \\
\hline Random Plasma Glucose & $\begin{array}{l}43 \mathrm{mg} / \mathrm{dL} \\
14 \mathrm{mg} / \mathrm{dL}\end{array}$ & $39 \mathrm{mg} / \mathrm{dL}$ \\
\hline Serum Cortisol & $690(171-536)$ & \\
\hline Serum GH & $>10 \mathrm{ng} / \mathrm{ml}$ & \\
\hline Urine Ketones & Negative & \\
\hline Post glucagon -glucose & $30 \mathrm{mg} / \mathrm{dL}(1.6 \mathrm{mmol} / \mathrm{L})$ & \\
\hline Serum TSH & $8.53 \mathrm{mlU} / \mathrm{ml} \quad(1-39)$ & \\
\hline Free T4 & $2.32 \mathrm{ng} / \mathrm{dL}(0.93-1.7)$ & \\
\hline Serum Insulin & & $16 \mathrm{mlU}$ \\
\hline Insulin-Glucose Ratio & & 0.41 \\
\hline PET scan (18 F DOPA PET) & & $\begin{array}{l}\text { Pancreas showed diffuse } \\
\text { enhancement with higher } \\
\text { intensity in head and neck } \\
\text { region. }\end{array}$ \\
\hline Genetic testing & & $\begin{array}{l}\text { Two heterozygous mutations } \\
\text { (Asp854Asn and } \\
\text { Arg1394cys) in the ABCC } 8 \\
\text { gene }\end{array}$ \\
\hline
\end{tabular}

\section{MANAGEMENT}

Glucose infusion was initiated at $12-15 \mathrm{mg} / \mathrm{kg} / \mathrm{min}$. Oral feeds with Dextrose fortified breast milk was also initiated. The baby responded well to treatment and infusion was tapered and stopped on Day 4.

Hypoglycemia recurred $(11 \mathrm{mg} / \mathrm{dL}(0.6 \mathrm{mmol} / \mathrm{L})$ necessitating glucose Infusion at a higher rate. Octreotide (Somatostatin analogue)

subcutaneously was initiated at $15 \mathrm{mcg} / \mathrm{kg} / \mathrm{day}$ to maintain euglycemia until Diazoxide was available. Commenced on Diazoxide $10 \mathrm{mg} / \mathrm{kg} /$ day (up to 30 $\mathrm{mg} / \mathrm{kg} / \mathrm{day}$ ) with which he maintained euglycemia and successfully weaned off glucose infusion.

He demonstrated appropriate response to Diazoxide and was discharged without any neurological deficit.

On follow up, patient developed hypertrichosis and the dose was reduced. Currently the patient is 4 years old, off Diazoxide and is doing well.

\section{CONCLUSION}

This case highlights the importance of prompt diagnosis of persistent hypoglycaemia in neonates $(\mathrm{HH})$ and prevention of complications such as neurodevelopmental deficits.

Majority of the affected newborns require high intravenous glucose to maintain euglycemia ${ }^{1,2}$ until definitive medical management with Diazoxide is started.

The diagnosis and treatment of this rare condition ( 1 in 50,000 births) have made tremendous progress over the years where genetic markers may help predicting spontaneously reversible hypoglycaemia and avoid irreversible surgeries.

\section{REFERENCES}

\footnotetext{
Zsuzsanna Molnar et al; 'Congenital Hyperinsulinism Caused by a De Novo Mutation in the ABCC8 Gene. EJIFCC. 2017 Feb; 28(1): 85-91. PMCID: PMC5387702, PMID: 28439221

Rozenkova K et al; High Incidence of Heterozygous ABCC8 and HNF1A Mutations in Czech Patients with Congenital Hyperinsulinism. Doi: 10.1210/jc.2015-2763.

Unöke Meder et al: Severe Hyperinsulinemic Hypoglycemia in a Neonate: Response to Sirolimus Therapy. Journal of Paediatrics Nov 2015 Volume136/ISSUE 5.

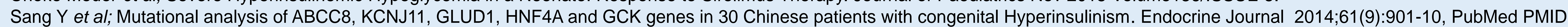
25008049

5. Tung JY et al; Clinical heterogeneity of Hyperinsulinism due to HNF1A and HNF4A mutations. J Paediatric diabetes 2018 Aug; 19 (5):910-916. doi: 10.1111/pedi.12655, PubMed.
} 